\title{
Identity, Ethnicity and School Experiences: Relocated Montserratian Students in British Schools
}

\author{
Gertrude Shotte
}

\begin{abstract}
This paper explores the issues of identity and ethnicity that confront relocated Montserratian students in British schools. It begins with a brief historical review of the ongoing volcanic crisis, then explains the circumstances within which the issues are framed. The paper argues that the merging of "old" and "new" forms of identity and ethnicity has affected relocated students' aspirations in various ways. Montserrat's education system evolved out of a colonial British-based curriculum that encouraged particular morals, which are not apparent in the British school system. These values remain an integral part of the Montserrat mores and thus are recognized as central to the island identity. In adjusting to their new cultural environment, relocated students have donned new identities that have inevitably clashed with traditional norms. This paper therefore explains how they have negotiated their ethnic/racial identities in relation to school and home, and how they have crafted new identities, while at the same time trying to maintain a desired level of "Montserratness." The assessment and inferences made in this paper are based on formal and informal research conducted with relocated Montserratians, particularly students and their parents/guardians, in different regions, but the main location is London.
\end{abstract}

\section{Résumé}

L'article se penche sur les questions d'identité et d'ethnicité avec lesquelles les élèves montserratiens déplacés sont aux prises dans les écoles britanniques. Il s'ouvre sur un aperçu historique de l'importante crise en cours, puis explique les circonstances entourant ces questions. L'auteure affirme que le mélange d'" anciennes » et de "nouvelles » formes identitaires et ethniques a transformé les aspirations des élèves de diverses façons. Le système d'éducation montserratien a évolué d'un programme issu du colonialisme britannique qui favorisait une moralité particulière, laquelle ne transparaît pas dans le système scolaire britannique. Ces valeurs font partie intégrante des mours montserratiennes et sont donc considérées comme centrales à l'identité de l'île. En s'ajustant à leur nouvel environnement culturel, les élèves déplacés se sont forgé de nouvelles identités qui sont fatalement entrées en conflit avec les normes traditionnelles. L'article propose par conséquent une explication de la manière dont les élèves ont négocié leur identité ethnique ou raciale relativement à l'école et à la famille et se sont créé de nouvelles identités, tout en essayant de maintenir un degré acceptable de "montserratienneté». Les évaluations et déductions contenues dans cet article s'appuient sur des recherches formelles et informelles menées auprès des Montserratiens, en particulier des élèves et de leurs parents ou tuteurs issus de différentes régions, London étant la ville principale des investigations. 
Montserratians we call ourselves

Colonists they call us

No anthem

No flag

No heroes

A people constantly searching

A nation needing its own

Identity

Nationality

Individuality

Merle Roach ${ }^{1}$

\section{Introduction}

he awakening of the Soufriere Hills Volcano on 18 July 1995 ushered in a roller-coaster existence for the residents of Montserrat. Numerous phreatic eruptions and pyroclastic flows caused volcanic activities to escalate to the point where only the North, one-third of the island, was deemed habitable (see Appendix I). It therefore gained the label "safe zone."2 By the latter half of 1997, the loss of the capital, Plymouth, together with significant disruption in utilities and social services, particularly schooling, influenced the exodus to "safer" shores. Persons relocated to various countries but a sizaable majority settled in the UK-a choice that seemed more practical possibly because of Montserrat's British Dependent Territories Overseas (BDTO) status.

I write from a position as educator, researcher, and relocated migrant. Because of my involvement in several support projects organized by community groups, Parent Teachers Associations (PTAs), and the Emergency Operation Centre (EOC), invariably I had to "work" alongside students and parents, from the onset of the crisis up until mass relocation began. These experiences, along with prior knowledge of the relocated students' educational milieu, as well as numerous complaints from relocated students, their parents, and other concerned persons, influenced me to investigate the students' educational experiences in the host country, Britain. ${ }^{3}$

My research into the school experiences of relocated Montserrat students revealed that they were stereotyped into two moulds-African Caribbean and refugee students. On the basis of descent and location, their Montserrat identity represents an African Caribbean identity that is defined by ethnicity. Nested in this ethnic boundary is an island identity within which the relocated students' educational experiences are interpreted. My concern with identity also focuses on their status as forced migrants/refugees, as they navigate their way through a multi-ethnic maze of identity clashes and dominant cultural influences.
This paper examines the dilemma that relocated Montserratian students in the British schools encounter as they struggle to understand the shifting patterns of identity and ethnicity that confront them in their new environment. It explains the interrelatedness between identity and ethnicity and relates the challenges that relocated migrants face in maintaining their national and cultural identity in the settlement process. Montserratians' national as well as cultural identity is linked to homeland-their "sense of place" and their "British" status. ${ }^{4}$

Like a common origin and a shared culture, one's "sense of place" is an integral part of his/her ethnic identity. ${ }^{5}$ Relocated Montserratians' "sense of place" is caught between "old and new ethnic identities."6 Negotiating the space between identities has been dominated by passionate articulations of connection to homeland, for attachment to land and place, to a large extent, defines the impressions about a Montserrat cultural identity. And this cultural identity, although severely challenged, remains the "connective tissue" between the "old and the new."7 The paper will therefore explain how relocated Montserratians' "sense of place" has been affected by the loss of "home."

\section{Interrelatedness: Identity and Ethnicity Explained}

Identity and ethnicity bear complex and varied definitions and by their very nature defy a strict definition. Both concepts have a common general core-culture. ${ }^{8}$ Identity and ethnicity denote an individual's sense of self-recognition and impart a sense of belonging to a reference group, whereas culture claims a set of symbolic generalities. Identity, ethnicity, and culture mean different things to different people. The processes and practices within which they are defined and interpreted are interconnected at various levels, as is acknowledged by various researchers.

Rosa Sheets acknowledges the link between identity, ethnicity, and culture, but points out that the connection does not represent a "one-to-one relationship." Sheets proffers this reason for the narrow distinction: "Ethnic identity formation and development is influenced by membership in an ethnic group identified as a distinctive social group living under the shaping influence of a common culture." 9

From Sheets's explanation, it is culture that influences ethnic identity. Avtar Brah puts forward a similar view by stating that identity is simultaneously subjective and social and that it is constituted in and through culture. ${ }^{10}$ Herein lies the inextricable interconnection between culture and identity, given that: "Culture is the symbolic construction of the vast array of a social group's life experiences. Culture is the embodiment, the chronicle of a group's history." 11

Sian Jones, too, does not support the one-to-one relationship mentioned earlier, but has, however, identified the 
integrated links between the concepts under discussion. For Jones, ethnicity includes "all of those social and psychological phenomena associated with a culturally defined group identity. . . . Ethnicity focuses on the ways in which social and cultural practices intersect with one another in the identification of, and interaction between groups." 12

The fact that the concept of ethnicity is closely related to the concept of "group identity" underlines a "sense and expression of ethnic difference" that gives members an opportunity to glorify their ethnicity without passing judgements on other ethnic groups. ${ }^{13}$ It is perhaps within this sense that ethnic identity "has come to be conceptualised less in terms of culture per se and more in terms of process," in that it has become "more fluid and flexible, created, manipulated, and negotiated." 14 With regard to refugees, ethnic identity is influenced in ways other than a meeting of former identities and new influences from the host society. It is also influenced by a forced migrant's "current relations with his/her country of origin as well as those with other exiles in their diaspora."15

It is against this background, and within the boundaries of interwoven, complex interpretations of identity and ethnicity, that I relate and illustrate the educational experiences of forced migrants. I begin by exploring the fluidity of the forced-migrant identity.

\section{Forced Migrants/Refugees and Identity}

Maintaining a national and cultural identity in a multicultural environment proved to be a challenging experience for relocated Montserratians, especially the students. Social and cultural theorists contend that identity construction is dynamic and fluid. ${ }^{16}$ It follows then that an individual's identity is not static, but is created and recreated to fit ongoing circumstances. ${ }^{17}$ For refugees, therefore, the malleability of identity formation is extremely vital since it "allows the experience of suffering and hardship to assimilate into symbolic understandings of who the collective ethnic group is and what it stands for." 18 Consider these parents' comments: ${ }^{19}$

No matter what happen to us here, we still Montserratians. If people call us refugee we still Montserratians and we should do what ever it takes to hold on to the Montserrat culture. But it ain't easy, for the way some of the children pick up the different habits from school if we don't put down we foot, they will forget where they come from. (Ellen, Parent)

It's bad enough for us adults to carry the Montserrat banner and show them who we are and what we stand for, but it is worse for the children. They under plenty pressure at school. ... we could do it but it is rough. (Clarice, Parent)
Another parent spoke of renouncing his Montserratness, albeit temporarily, in order to get accommodation sorted out:

I just had to forget that me a one Montserratian. I had to behave like everybody else to get what me want. ... If you did hear me you wouldn't believe. . . Anyway sometimes you have to be different to get what you want. (Walter, Parent)

From the foregoing comments, I conclude that it is the shifting and bouncing back and forth between attempts at "fitting in" and the struggles to maintain a Montserrat identity, rather than the recognition of what the collective Montserratian group stands for, that presented the challenges for relocated students and their parents. Tom Lam and Christopher Martin reported on a similar situation for Vietnamese refugees in London as they tried to "reconstitute themselves as a community." ${ }^{20}$ African Caribbean refugees too faced comparable dilemmas in Canada. They were so concerned with settlement and survival issues (meeting basic needs) that maintaining their cultural identity proved to be rather difficult. ${ }^{21}$

I have also noted another area of conflict that posed challenges in maintaining a Montserrat identity-"cultural equalizing," The placing of relocated Montserratians in a "refugee" category to allow them to have basic social services has rendered differences of culture and socio-economic strata into one "refugeeness." In this way, "Montserratness" has not only become obscured on the "refugee" playing field, but is also restricted to a Montserrat family/community setting. This continuous shifting between identities, coupled with the fear of losing the Montserrat identity, has caused much concern for relocated Montserratians with regard to past identity maintenance. Some parents have confided that they are worried that their children would grow up more "English than Montserratian," and therefore would be unable to pass on Montserrat traditions to successive generations.

The students expressed other concerns. This does not mean, however, that they were not concerned about maintaining their Montserrat culture for, generally, they spoke of wanting to continue doing traditional cultural arts at school. ${ }^{22}$ Their concerns focused on what circumstances caused them to be "refugees"-what they were before relocation and what they were forced to become. One student lamented: "If the volcano didn't come, we would not be refugees. ... We would be in Montserrat living good life" (Khalil, Year 7). Another spoke of not being a refugee if she was "still living in the safe zone, even it was scary" (Alice, Year 8). Yet another spoke of mixing with the many students "from every country" who made up his school population as an unerving and intimidating experiencing. 
Before relocation, some students did not realize the scope of differences that exist among other cultures. They viewed "ethnic identity" through a Montserratian lens, for their lived experiences were defined by encouragement, support, and "protection" of the entire Montserrat community. This "sheltered" existence did not prepare them for the upheaval and accompanying uprootedness that turned them into "refugees," nor did it prepare them to deal with culture clashes and differences.

A first-wave migrant recognized the uphill struggle that relocated Montserratian students faced in retaining their cultural identity as they tried to assimilate into British society. ${ }^{23}$ Cathy Aymer pointed out that not all of them would respond positively to efforts made by UK-based Montserrat organizations "to keep Montserratness alive." She noted that while some would do extremely well, others would be seduced by "the destructive aspects of British society" and thus become "casualties of the system." 24 This Montserratian's anxieties were voiced against the background of her own reflections about her identity and sense of belonging as a Montserratian living in London. Admittedly, as a voluntary migrant, Aymer's reflections on her identity were not perceived through the "distorted" lenses of "refugeeness." But her welcome to England was "unbelievably traumatic"; she experienced a similar sense of alienation and disappointment, and faced comparable accommodation problems. ${ }^{25}$

What has emerged from Aymer's experience and observation is that symbolic understandings of identity do not only happen on a group level for there is the central task of analyzing one's own identity. This implies that while relocated students were battling to maintain a Montserrat identity and struggling to assimilate their "refugee status," they were also juggling various levels of individual identity construction as each sought to craft a "new self-identity."

Education is generally regarded as one of the principal means of helping refugee students to assimilate into the mainstream school culture. ${ }^{26}$ Jane Kroger argues that it is the job of the school "to meet genuine needs, and allow opportunity for individual talent to be expressed and channelled into real social roles." 27 But this study shows that it was within the school environment that relocated students confronted the greatest challenges to maintaining their cultural identity. It was also the school setting with its many and varied cultural influences that inspired relocated parents' trepidation relating to identity maintenance and cultural conflicts.

\section{Maintaining a Montserratian Identity in School}

Relocated Montserratian parents were extremely concerned about their children's reaction to the "corrupting influences that surround them in the schools they attend" (Martha). The major issues that angered the parents are subsumed under these themes:

A. disrespect for teachers,

B. "undesirable dressing,"

C. "bunking off," 28

D. threatening to call Childline UK.

In Montserrat, there were occasional incidences with respect to $\mathrm{A}$ and $\mathrm{B}$, and perhaps $\mathrm{C}$. But D was unheard of; Montserrat society did not accommodate a "Childline" service, hence the parents' extreme concern.

The relocated students in question have acknowledged their parents' concerns, but felt compelled to "follow the crowd." One student confessed, "If I don't dress like them I would not have any friends" (Davida, Year 10). Another said, "They [the other students] would call me 'soft' if I don't go with them" (Kester, Year 11). These two students' expressions represent the views of the majority of relocated students.

It is quite clear from the interviews that dealing with culture shock proved to be a threatening and depressing experience. Admittedly, this can be said of any migrant whose previous experiences clash with aspects of the new environment. However, it becomes more problematic for forced migrants who have added anxieties and stresses resulting from the traumatic experiences that caused the forced migration, as well as the frustration of resettlement. $^{29}$

For relocated students, the "bonding function" proved most effective in helping them to cope with the anxieties that resulted from culture clash. William Cros,s Jr., et al. advance that "bonding" allows persons to derive meaning and support from an affiliation with, or attachment to, other members of their ethnic group. ${ }^{30}$ I observed that "bonding" was evident among the relocated students whose friendship groups consisted primarily of persons from similar ethnic groups, that is, other students of African and African Caribbean origin. I also noted that they gained much emotional support from their Jamaican counterparts, possibly because of the "Caribbean connection" and the common dialect that they speak. It was this affiliation that provided the support that relocated students craved as they tried to absorb the "shock" experienced on entering a "foreign" school environment. "Bonding" seemed strongest in one particular school where all staff members were of African Caribbean origin. It was also at this school that relocated students felt most welcome.

In addition to providing students with a renewed sense of optimism and autonomy, giving a warm welcome to refugee children has been shown to aid the recovery from culture 
shock. ${ }^{31}$ But this was not the experience of Silda, a Year 9 relocated student who reported that for her first few weeks at school she cried every day because she missed Montserrat, was very unhappy, and had "nobody to turn to."

Another student related:

It was very hard at first, I was on my own. Sometimes I felt like crying, but I am confident now and I am more independent. My English teacher was very nice to me. In Montserrat it was different all the teachers helped you but here you have to push yourself if you want to succeed. (Kate, Year 11)

Silda's and Kate's experiences show the difficulty that some relocated students endured in merging past and present identities. Silda appeared more susceptible to the pressures of alienation, while Kate recognized the need to push herself, perhaps with some encouragement from her English teacher, who was the school's Ethnic Minority Achievement Grant (EMAG) coordinator. ${ }^{32}$

Curtis had an experience similar to Kate's but viewed being in a multicultural school as an advantage to learn about other cultures:

I meet students from many places. They speak different languages and they even have different religions. I enjoy learning about their culture and I tell them about Montserrat. I miss Montserrat and the things I used to do but I am trying to get used to the way the schools operate. (Curtis, Year 10).

Curtis's experience fits with the "bridging function" that Cross, Jr., et al. propose as an identity operation. Bridging allows a person to move "back and forth between black culture and the ways of knowing, acting, thinking, and feeling that constitute a non-black world view." 33 This function allowed Curtis to gain a non-Montserratian world view while at the same time holding on to his Montserratian cultural frame of reference.

Jonelle too was able to appreciate the difference she confronted as she immersed herself in the realities of her new school environment. She not only tried to get accustomed to her new school culture, but she also admitted that she missed it when she returned Montserrat for a short period:

When I went to visit Montserrat, I realised how much I missed home. But when I came back to England, it made me have second thoughts about going back. It's not too bad here once you get used to it. (Jonelle, Year 7)

The above experiences suggest that as students strove for successful integration, they were creating new cultural identities in the process, although this may be a transitory adaptation. Curtis as well as Jonelle can be categorized as low salience identity students for difference in culture did not prevent them from making reasoned decisions or making the best of being in a multicultural school setting. I equate Jonelle's experience to what Cross, Jr., et al. dub "codeswitching." This function "allows a person to temporarily accommodate to the norms and regulations of a group, organisation, school or workplace." 34

I noted too that there was also an element of "individualism" in Jonelle's case. The "individualism" function, according to Cross, Jr., et al., "is the expression of one's unique personality." 35 They further explained that when a person acts in a race-neutral manner in accord with his/her self-concept, it is the "individualism" function that motivates him/her to utilize this identity strategy. Jonelle was able to identify herself with the norms of the school as well as express herself in accordance with her individual outlook and persona.

Obviously, individuals do not move through the stages of adjustment and acculturation at the same rate, even if they are from the same cultural background. Elizabeth Coelho notes that students who are caught between a desire to succeed and desire to be accepted by their peers, in order to overcome marginalization, often adopt "an oppositional stance towards school" - a situation that may result in further marginalization and exclusion from school and/or home, and ultimately a loss of the educational success that is desired. ${ }^{36}$ This seemed to be the case with Kester, a relocated student who was excluded from school three times in his first year of schooling in England. Kester has repeatedly expressed his disgust at school and with teachers whom he claimed acted unfairly towards him because he is black. But his exclusion, whether rightly or wrongly meted out, did not gain favourable acceptance from some relocated students at his school and some members of the relocated Montserrat community, who share this view: "He [Kester] let us [relocated students] down. And he make his family shame" (Shanelle, Year 7). Extreme and/or poor behaviour is not the norm for the Montserrat school culture. Hence Shanelle's and others' aghast reactions to Kester's dilemma imply that such behaviour threatens what "Montserratness" represents.

Kester's ethnic identity undoubtedly had a direct bearing on his exclusion case for research has shown that African Caribbean students were more likely than other groups to be excluded from school. ${ }^{37}$ These students who were excluded from school claimed that they were victims of racial prejudice although some teachers tend to argue that they do not see skin colour among the children they teach. ${ }^{38}$ But in analyzing similar cases to Kester's, I conclude that teach- 
ers' attitudes to racial identity, which is an integral part of social identity development, have implications for relocated students' educational progress.

The issue of racial identity brings into focus the "buffering identity function" of Cross, Jr., et al. They have described this function as "those ideas, attitudes, feelings and behaviours that accord psychological protection and selfdefence against everyday encounters with racism." 39 In other words, "buffering" prepares one for racist encounters, leading to greater personal control. But I posit that the relocated students, unlike their British-born African Caribbean counterparts who have always lived with racism, lacked the psychological protection and self-defence to which Cross, Jr., et al. alluded. Whether British-born African Caribbean students have mastered "buffering" is open to question. The comparison was made for this reason: most teachers have put a blanket label on all students of African Caribbean descent; no distinction is made in handling contentious issues.

Experiencing face-to-face racism was "foreign" to Montserratian students prior to their relocation to England; thus they did not anticipate such racist encounters, as is implied in this sentiment:

Before I came to England, I used to think that it was a nice place. I used to think that people would be nice to you and want to help you. Now I know it is different-not the same like Montserrat. Racism everywhere-in school, in church, everywhere. (Arnold, Year 10)

Like Arnold, most relocated students were not prepared to confront racism and racist attitudes, at least to such a large extent. It was not evident from the group discussions and the one-to-one interviews that the relocated students had employed the "buffering function" to counteract racist experiences. Also, it was not readily apparent that they had developed the "buffering" capacity that would have allowed them "to filter out racist information." 40 It was perhaps the use of the "bridging function" among low salience identity relocated students that helped them to blunt the pain that arose from unavoidable racist encounters.

It is probably a good practice for relocated students to begin to develop the "buffering identity function" to a capacity that will allow them to filter "racist information" and let positive, non-racist experiences help them to regain and/or sustain their pre-relocation educational aspirations, as they rework their identities to accommodate the changes in their new school environment.

\section{Adapting and Combining Identities}

Instead of simply accepting the "mixed bag" that the host society offers, Camino observed that, generally, refugee students often add new slants to their identities by using symbolic dimensions that are grounded in their own experiences. ${ }^{41}$ I fit Nadia into this categorization. I noted the following from an observation session at Nadia's school: Having had an interesting debate-Environmentalists versus Developmentalists - a class of Year 8 students was given the task of designing posters in preparation for a demonstration to protest their side of the issue. Two posters (Nadia's and a British student's) illustrate how Nadia utilized symbolic dimensions from her past social experience as she struggled to identify with a new cultural experience.

In comparison to the other student's, Nadia's poster bore an extremely mild protest. Her verbal protests seemed even milder, for while other students responded with frenzied chants, Nadia placidly responded with an approving "yeah, yeah." The general tone of her protest appeared to be one of peace and love, as indicated by the hearts on her poster (see figure 1). By contrast, the other student's poster and demonstrative responses portrayed a strong sense of antipathy, abhorrence, and antagonism (see figure 2).

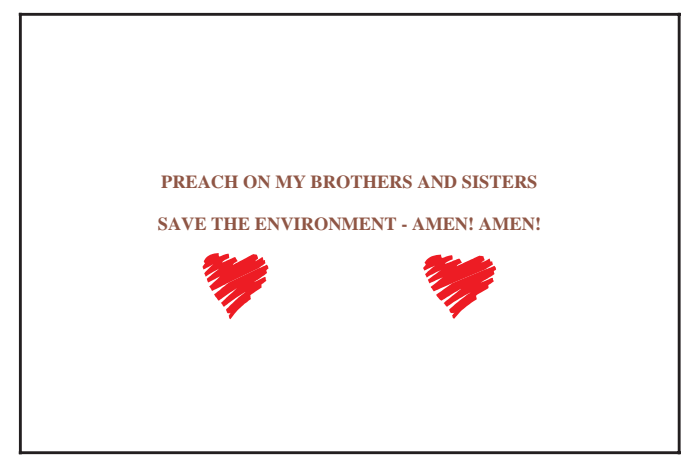

Figure 1

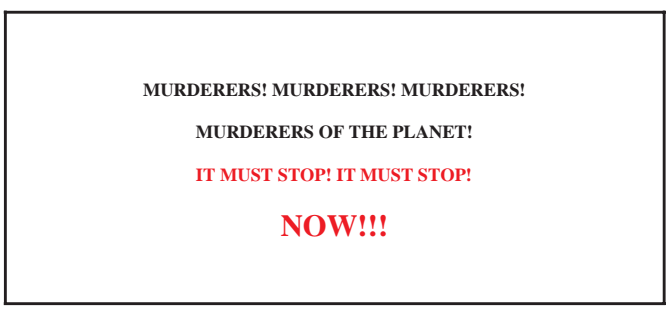

Figure 2 
On observing Nadia's presentation, one may reasonably conclude that she did not feel a similar loathing for destroyers of the environment, as was demonstrated by the other students. But this is not the case, for in a follow-up discussion with Nadia, she confirmed that she was "all for preserving the environment." Like Nadia, the average Montserratian student put a high value on preservation of the environment. This statement was made on the basis of my experience in Montserrat, working on several environmental projects with Nadia and other students. The focus here, however, is not on students' perceptions of environmental concerns, but rather on the clash of cultures; Nadia was caught between two cultural worlds-the "new" and the "old." It was evident that her attempts to shift, albeit temporarily, from spiritual values that she was socialized to cultivate were unsuccessful.

Clearly, the new "attitudes" that Nadia confronted in this particular lesson clashed with values that were inconsistent with her pre-relocation experiences. Interestingly, although failing to shift fully, Nadia did not reject her new experiences because they conflicted with her values, but rather she reorganized her values to fit her new experiences. Her poster demonstrates that she was still "holding on" to her "peaceable" pre-relocation sense of self while participating, to a comfortable degree, in an episode that clashed with her beliefs. One school of thought suggests that such an action, that is, identifying with a new sense of self, is one way in which self-consistency can be maintained. ${ }^{42}$

The creation of refugee student identities in a multicultural school environment can be very successful but also often painful. ${ }^{43}$ From the various experiences reported by relocated students, I take the "good" experiences to be the successful ones and the "bad" to be the painful. Constructed identities are related to aspects of culture, language, and religion, and most of the personal accounts tell a story of success and/or pain: that is, the students' experiences were characterized by a range of conflicting emotions. For example, Kanta reported that she liked her school and was enjoying the learning experience, but lamented:

I hate to see the students smoking and I don't like the attitude of some of the students at school. They do not respect the teachers at all. They never listen when the teachers talk to them for their good. In Montserrat we never behaved like that. (Kanta, Year 11)

Kanta's remark represents the views of a vast majority of relocated students. It highlights two types of identity-individual and cultural. It also implies that identity clashes result in emotional pain. The students categorically expressed their disgust at the undesirable habits that some students practised. These include: swearing in class, smoking, being disrespectful (especially to teachers), and wearing "anything they want with their uniform" (Shanelle, Year 7). Yet, some have admitted engaging in these very undesirable practices because they were pressured by other students to conform-another example of "codeswitching." Nevertheless, this is the school climate in which relocated students were striving for educational excellence, so they were forced to recognize and accept these realities as they struggle with various identity constructions.

Undoubtedly, this was a clash of two very different school cultures; and invariably, trying to adapt, mix, and balance the cultures proved to be an emotional strain. The school dress code in Montserrat did not allow for "bizarre" hairstyles, ${ }^{44}$ nose rings, earrings (for boys), and immodest dressing - a stark contrast to what is allowed in British schools. A relocated student explained that he wore an earring because "everybody is doing it," and if he did not follow the trend he would be harassed and ostracized from the boys' clan. Another student explained, "I only wear it (an ear-ring) when I am at school and when I go out with my friends. I do not put it in at home. I can't let my mother see it" (Angus, Year 11).

A similar case was reported for another relocated female student who wore a nose ring. Yet another took off her woollen socks when she got to school and donned a "nice" pair, because the woollen socks were "too old-fashioned" and they "don't go well" with her shoes. Pieces of clothing were even hidden in school bags and later worn at afterschool activities. I observed that many relocated students sported a distinct duplex identity-they behaved in one way at school and another at home and they continually shifted from one role to the other. At some times, when it suited them, they maintained their traditional norms; at other times, these very traditional norms were pushed aside for new identities that fit the existing circumstances.

The "relational self," a form of self-definition, gains its strength from "the constant barrage of imagery and information" produced by communication technology. ${ }^{45}$ With reference to relocated students and this study, the "relational self" is nurtured by an infiltration of influences of a more dominant culture. Inevitably, constant exposure to these influences in a school environment will play a major role in relocated students' development of new identities. It is this scenario that has raised "serious concerns" and invoked "real fears" among relocated parents. In general, parents' anxieties were reflected in this parent's comment:

The problems that our children are having is a serious matter. We cannot ignore it and hope that it will disappear. The influences from the British culture are very strong and some children 
do not have the strength to resist the bad ones. It is a different way of life and we have to help them to deal with it. Some of them have already lost their Montserrat values-what they know we stand for, and we can't afford to let all of them go down the drain. (Teresa, Parent)

Another parent hoped that "the damage" that had been done "is not beyond repair" (Melvin) and that the identity conflicts would be transitory. But it is problematic to attach a time limit to "transitory" especially if the students realized that they can benefit from both worlds (home and school) by maintaining an assortment of alternative identities. Besides, some relocated students seemed to have mastered the art of "doubling" by displaying a high degree of behavioural flexibility - a characteristic of a "pluralist individual." 46 The fact that some parents were unaware of "what is going on with de children dem" (relating to doubling) bears this out.

Generally, the parents felt that the solution to such "an awful situation" (Martha) was to "take every one of them back to Montserrat" (Harold). Another parent bemoaned, "Look what me come to. Who would believe that me would come a England to get dis kine a problem. Only God could help us [relocated parents] wid we children" (Ellen, Parent).

John Head posits that it is not unusual for adolescents to make attempts to demonstrate autonomy and an independence from parents. ${ }^{47}$ However, such adolescent behaviour is not demonstrated in a vacuum but rather within the confines of a culturally defined group identity, usually an ethnic identity. In an analysis of adolescent friendship networks, Rampton in a study of "language and adolescent ethnicity" informs that ethnic descent was an important organizing principle in adolescents' associative networks. ${ }^{48}$ It is reasonable to conclude, therefore, that the seeking of autonomy and independence from parents, together with constant identity reconstruction have put extraordinary emotional strain on relocated students' psyches-a situation that has impacted negatively on their overall educational progress. This suggests that the adaptation to cultural changes entails more than assimilation into the mainstream; other interrelated phenomena like the dimensions of human development are also involved. As an integral part of ethnicity, one's "sense of place" is one of the phenomena that plays an important role in the adaptation process, as is noted in the next section.

\section{A "Sense of Place"}

When people flee from the threat of death and total dispossession, the things and stories they carry with them may be all that remains of their distinctive personhood to provide for future continuity.

Parkin, cited in Couldrey and Morris ${ }^{49}$

Relocated Montserratians' flight "from the threat of death and total dispossession" has not obliterated their strong emotional attachment to their homeland. Their 'sense of place' remains central to what constitutes "Montserratness." Some relocated students had the opportunity to express this cultural awareness. I refer to two examples:

I was commissioned to run a small theatrical project for the School Summer Festival. ... I planned a dramatisation of some poems. . . . . For one particular aspect of my plan I needed speakers who could speak with a West Indian accent or read Jamaican dialect. .... They (two relocated students) were wonderful, committed, hardworking, imaginative, responsive to ideas, full of initiative, brought their own props and music. (Teacher CP)

In one of our English classes, I asked them (relocated students) to write about their country, what it is like, what it was like living there. They all were quite interesting. One of them was excellent-very well written-a very enthusiastic and informative description. (Teacher KL)

As noted earlier, attachment to land and place is one way in which feelings about a Montserrat cultural identity can be interpreted. Language, that is, the Montserrat dialect, is another. Thus, CP's theatrical project played a vital role in allowing the two students concerned to reinforce their "sense of place."

A similar sense of island identity was noted in the students' writings (from Teacher KL's task). An analysis of these accounts revealed that the students' thoughts were penned with a strong sense of individual and collective identity and clear definition of the students' "sense of place." The writings were grounded within a set of traditional and cultural orientations that the students recalled with mixed emotions-ranging from pleasure to misery, from acceptance to inadequacy, from despair to cautious hope and optimism. All the stories were developed along a similar route and the ideas were connected by the same historical links. The stories did tell a tale of students' "distinctive personhood and nationhood." These include stories about pre-volcano Montserrat, descriptions of the volcanic activities, and reasons for relocating. The accounts also showed an awareness of students' perceptions of the differences in cultural orientation, as noted from this excerpt from one of the accounts: 
I like the life in Montserrat. I wish at this very moment I was in my hometown, where there is no winter or fast-going life. You are able to walk freely in Montserrat without anyone stepping into you, unless they are not minding their business. (Roselyn, Year 9)

An expression of cultural identity in any fashion is noted by the editors of Forced Migration Review to be "a powerful way to maintain a community's mental and physical health" and restore their dignity after the trauma of exile. ${ }^{50}$

It is a common practice for relocated Montserratians to chat about "what's happening at home" whenever and wherever they meet. From these informal discussions, I noted that the parents/guardians had followed a similar trend (as in the students' writings) with regard to reflections on life in Montserrat. This suggested that attachment to land and place remains the backdrop against which relocated Montserratians interpret their feelings about their cultural identity. And given that "sense of place" is central to ethnic identity, ${ }^{51}$ it is reasonable to conclude that relocated Montserratians' sense of place is intricately linked to their attachment to land. This appears to be what is suggested in this excerpt from a conversation I had with a relocated parent:

P: You know me always say if dey sell Montserrat dey sell me with it.

R: I really didn't expect to find you here.

P: A no a did say a wud be de larse wan to leave, but a had to leave [I used to say I would be the last person to relocate, but I had to leave].

R: What happened?

P: De chilren. Deh ejukashun kom fus an a warne to help dem, but Montserrat iz stil me hoam. Me karn dun wid Montserrat [The children's education comes first and I want to help them, but Montserrat is still my home. I am not finished with Montserrat] (Raphael, Parent).

Similar expressions to Raphael's were voiced by other relocated migrants. Janice Panton and Robert Archer assert that relocated Montserratians have suffered a double loss - loss of house and possessions, and loss of the society itself. $^{52}$ They have also acknowledged that Raphael's sentiments are common among Montserratians: "People carry a potent image in their minds, of a island emptied of its people. . . . They feel real and sensible anxieties. One woman said: 'We are grieving over our country'. The volcano threatens to destroy 'home' at almost every level."53

But there is much more to this deep-rooted emotional attachment to land than having material possession. In the "safe zone" (the North) where most of the land is privately owned, many individuals have constructed items in particular places. These items (of which gravesites are among the most important) according to Panton and Archer bear "personal and cultural and spiritual attachments." 54

The foregoing reinforces relocated Montserratians' emotional bond to their native land. But forced migration has thrust upon them new concepts of place, space, and time. Thus, they are forced to acknowledge the cultural shifts, no matter how small, that are developing with their new lifestyle. But even with this acknowledgement, expressions like these are common: "Montserrat is still there. Montserrat still nice. . . I live here but my heart is in Montserrat.... Even though the volcano is there and things are not the same I will still hold on to Montserrat culture" (Val, Parent).

In trying to hold on to Montserrat culture, the new identities that are being created are fitted into an existing perception of a sense of place, for representations nearly always tended to be framed within images of pre-volcano Montserrat. For example, during an interview session, when asked whether her friends visited her at home, a relocated student replied: "Not yet-when we get a nice house like the one we had in Montserrat-with everything in it" (Alice, Year 8). In my field notes, I wrote, "like parent, like child," for I received a similar summary from Alice's parent on the same issue of "hospitality." Such an attitude may provoke a reaction of "stretching things too far," but it was mentioned to emphasize that every aspect of relocated migrants' "new" life that was deemed worthwhile and desirable was examined and contrasted against a Montserrat background.

Clearly, a strong sense of an island identity has remained with relocated Montserratian migrants — an identity within which a sense of self and a sense of place are interpreted. Such an affiliation to land seems necessary since their national identity is defined by location rather than by citizenship. A BDTO status makes allowance neither for British citizenship, nor for the status that nations attain on gaining political independence. By strict definition then, persons who were born in Montserrat, along with those who were naturalized as BDT citizens, have no national identity. In this context, therefore, relocated Montserratians remain in a limbo, somewhere between self-identity and pan-ethnicity, a gap that even the acquisition of several identities would find difficult to bridge. The next section explains how a limbo position was achieved and how it affected identity formation among relocated migrants.

\section{Identity and "In-betweenness"}

I view this section as important since some relocated migrants' choice to relocate to England was based on a percep- 
tion of essential sameness-"we are British." It was a false sense of identification with "Britishness," perhaps influenced by being holders of "category-5 British passports," that blinkered some parents into believing that the Montserrat and British education systems operated in the same way.

Clearly, a BDTO status has positioned Montserratians in a political limbo. Prior to 1995 , the ambiguous nature of this positioning seemed to have gone unnoticed. And although political status was given some consideration when persons began to relocate, it was the mass relocation in 1997 that seemed to have brought this "in-betweenness" into sharper focus, perhaps heightened by the harassment some received from immigration officials when they presented their "British" passports.

Consider this experience: "They (immigration officials) 'treat us like dawg.' They take we passport and tun it inside out ... and so they watch me up and down. Although the see de passport mark British, they still mek me and de children wait for along time before they let us go" (Sammy, Parent).

Sammy's case is not an isolated one. "In-betweenness" creates in those who experience it an awareness of inferior and superior "otherness" that heightens the need of belonging, hence the constant yearning to sort one's position. Bhabha has developed the concept of "hybridity" to describe a way that spaces in between might be negotiated. This, Bhabha contends, is possible if one constructs "cultural authority within conditions of political antagonism." 55 This entails more than an integration of culture as proposed by theories of multiculturalism. It involves an in-depth examination of political, economic, and social ideologies from which the aims and practices of naturalization are derived. Arber offers this explanation of Bhabha's suggestion:

Bhabha's concern is to demonstrate ambivalence within colonial discourse, to find instabilities of power through which anti-colonialist resistance is no longer powerless, to define a place where hybrid strategies open new spaces for negotiation. Ambivalence works within discourses of the coloniser, so that the authority is undermined even as it is asserted. ${ }^{56}$

To express dissent within colonial discourse with a view to finding weakness within the power structure is a challenging but reasonable task under "normal" circumstances. However, for Montserratians who were forced to relocate to England because of an ongoing volcanic crisis, and whose host is their colonizer, this seems a tall, if not impossible, order. Besides, some relocated migrants may lack the gall to challenge a host whose education system "provided the foundation for their educational achievement" (Edwin), despite the noted biases such as textbooks that conveyed positive messages about England and negative messages about the indigenous population. Such an attitude lives on despite the fact that the then-education system "served a vital function in sustaining the coloniser's dominance." 57 Consider these parents' expressions:

Yes we suffer injustice and yes they (the British government) treat us badly but they not all bad. They used to help us in some little way ... (pause), (laugh) ... I remember those good old school days. Anyway, we are not a position to do anything about it ... at least not now. They are in control, they brought us here ... that mean 'they have the handle and we have the blade', we cannot beat the system. (Jamie, Parent)

You see this situation that we find ourselves in, it is the children who will suffer most. But we can't give up, they need an education and we have to sacrifice many things to make sure that they get it. We here already so we have to take the sweet and the sour and move on. (Sarah, Parent)

These parents' seeming apathy is not representative of a lack of concern about relocated migrants' status as "in-betweeners," but rather a recognition that under present circumstances it is futile to attempt to challenge an authority that is so strongly asserted. Another parent spoke of "resisting the temptation to take on the system just for the sake of the children's education" (Walter). Although a sense of powerlessness and helplessness was prevalent among most parents, preoccupation with the continuation of their children's education remained top of their agenda.

Battling with the ever-shifting, contradictory identities together with the fallout of forced migration has left relocated Montserratians with insufficient spatial and temporal reins to create situations where they can negotiate their "in-between" spaces with a view to constructing a solid political/national identity. I surmise that only when particular concerns are resolved will they begin to examine whether hybrid strategies can indeed "open new spaces of negotiation.” Arguably, filling in a political space may symbolize a sense of "cultural authority within conditions of political antagonism." It does not necessarily represent, however, the acquisition of a fixed political identity since identities are always shifting and reconstructing themselves "against the representation of others." 58

\section{Conclusion}

The paper focused on the multi-faceted interrelationship that exists between identity and ethnicity and the role that culture plays in their development. This interrelationship 
was noted to have manifested itself in the various school experiences of relocated Montserratian students. My line of argument was sustained by presenting, from a broad literature base, scholarly theories and reasoning that paralleled the relocated students' experiences.

The main point of reference for the discussion on identity was Montserratian-born black students now living in London. I located different school experiences of relocated students and fitted them into contexts that appeared to represent "the black identity." Buffering, bonding, bridging, codeswitching, and individualism are the functions that Cross, Jr., et al. have noted to make up the black identity profile. I noted that different situations necessi- tated the utilization of different operations-singularly and/or as a mixed bag.

Ethnicity encompasses a shared culture and/or language as well as a "sense of place." An emotional attachment to land defines a "sense of place" for relocated Montserratians whose identity is geographically rather than politically defined. Perhaps it is the "in-betweenness" defined by an indeterminate state, and created by the deliberate political and racial manoeuvres of host country Britain, that has inspired relocated Montserratians to embrace a purposeful sense of survival in an "unfriendly" society, for the sake of their children's education.

\section{Appendix 1}

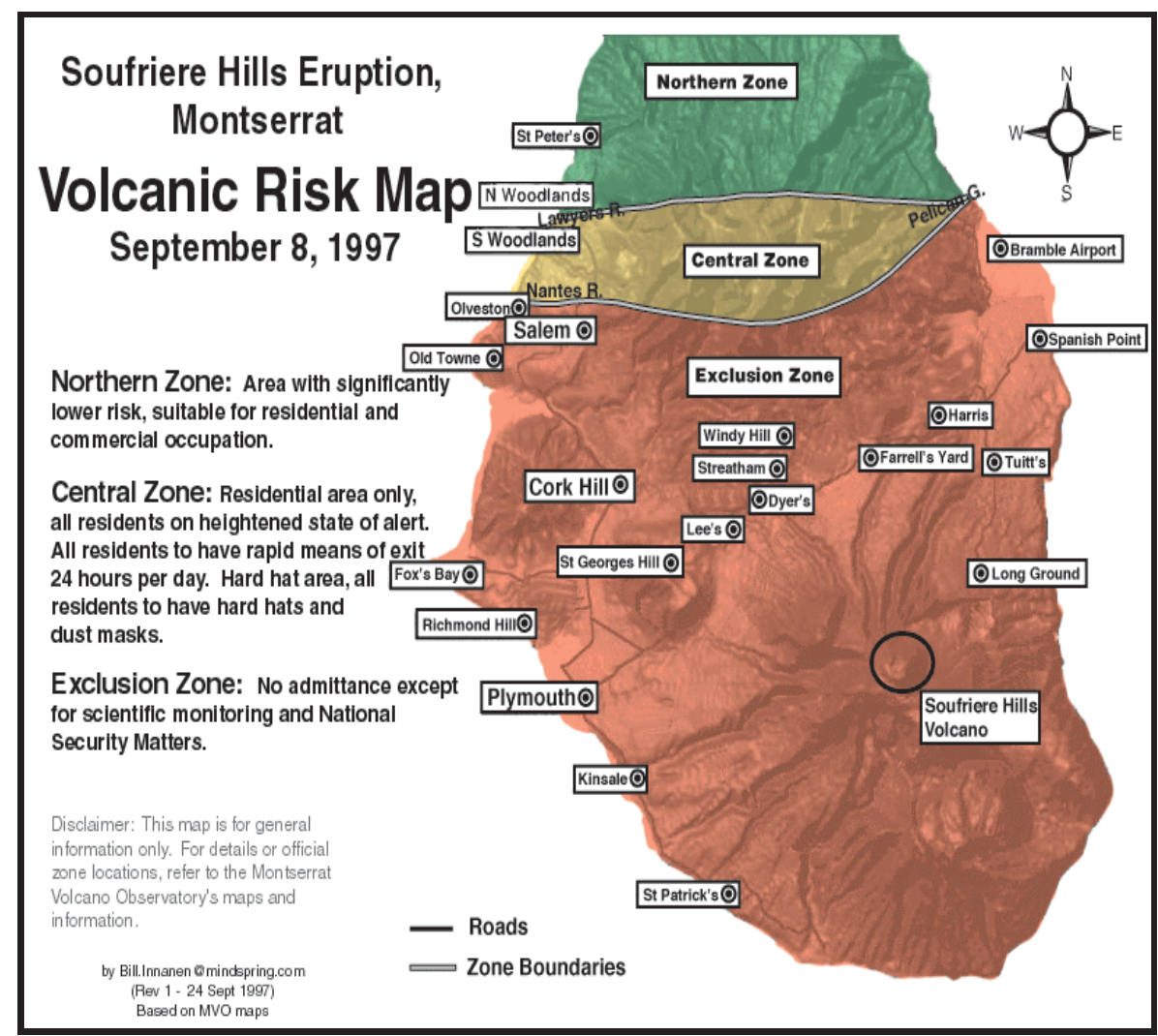




\section{Notes}

1. Merle Roach, "In Search of Ourselves," in Hope: Fiftieth Anniversary Anthology of Poems, ed. H. Fergus (Manjack: University of the West Indies School of Continuing Studies, 1998), 110.

2. This does not mean that the North is totally safe, for heavy ash-falls are known to have occurred in the North. It is the most appropriate place to reside under the ongoing volcanic circumstances.

3. Numerous complaints and concerns relating to students' educational progress were reported by parents, social workers, teachers, and other concerned citizens to the Montserrat Government United Kingdom Office (MGUKO) and Montserrat Community Support Trust (MCST). These complaints revealed that relocated students were experiencing educational problems of various kinds, and that their parents were deeply concerned about their children's educational plight.

4. Despite their possession of a "British" passport, the status of Montserratians, in a strict sense, was in limbo. In 1998, their colonial title was renamed British Dependent Territory Overseas (BDTO), a status that did not allow British citizenship. In May 2002 British citizenship (BC) was offered to all BDTOs. The data for this paper was collected before $\mathrm{BC}$ was offered.

5. Ben Rampton, Crossing: Language and Ethnicity among Adolescents (London: Longman, 1995), 297.

6. The "old" ethnicity gains its denotation mainly from geographic location. It refers to relationships based on "the linkage of similar people whose social identity was formed by influences from outside the society in which they lived." The "new" ethnic identity depends less on geographic location and focuses more on "the highlighting of key differences separating one group from another." Ibid., 295.

7. Homi Bhabha, "Cultures In-between," in Questions of Cultural Identity, ed. S. Hall and P. du Gay (London: Sage Publications, 1996), 54.

8. Ruth Krulfield and Linda Camino, "Introduction," in Reconstructing Lives, Recapturing Meanings, ed. L. Camino and R. Krulfield (London: Gordon and Breach, 1994); Maureen Slonim, Children, Culture and Ethnicity: Evaluating and Understanding the Impact (London: Garland Publishing, 1991).

9. Rosa Sheets, "Human Development and Ethnic Identity," in Racial and Ethnic Identity in School Practices: Aspects of Human Development, ed. R. Sheets and E. Hollins (London: Lawrence Erlbaum Associates, 1999), 92 and 93.

10. Avtar Brah, Cartographies of Diaspora: Contesting Identities (London: Routledge, 1996), 21.

11. Ibid., 18.

12. Sian Jones, The Archaeology of Ethnicity: Constructing in the Past and Present (Boston: Routledge and Kegan Paul, 1997), 1.

13. David Gillborn, Race Ethnicity and Education: Teaching and Learning in Multi-ethnic Schools (London: Unwin Hyman, 1990), 7.

14. Krulfield and Camino, $x$.

15. Ibid., xi.

16. Jonathan Rutherford, "A Place Called Home: Identity and the Cultural Politics of Difference," in Identity: Community, Cul- ture, Difference, ed. J. Rutherford (London: Lawrence and Wishart, 1998); Kay Deaux, "Personalising Identity and Socialising Self," in Social Psychology of Identity and the Self Concept, ed. G. Breakwell (London: Surrey University Press, 1992).

17. Linda Camino, "The Dynamics of Culture Change and Adaptation among Refugees," in Reconstructing Lives, Recapturing Meanings, ed. L. Camino and R. Krulfield (London: Gordon and Breach, 1994); A. Eckermann, One Classroom, Many Cultures: Teaching Strategies for Culturally Different Children (Sydney: Allen and Unwin, 1994).

18. Camino, 1.

19. Some of the parents' and students' responses are recorded in the Montserrat dialect.

20. Tom Lam and Christopher Martin, "What's Schooling For? The Vietnamese in the British Education System," in Refugee Participation Network (RPN) (Oxford: Refugees Studies Programme, 1996), 23.

21. Elizabeth Coelho, Teaching and Learning in Multicultural Schools: An Integrated Approach (Clevedon: Multilingual Matters Ltd., 1998), 20.

22. Prior to relocation the students participated in the Ministry of Montserrat's Bi-annual Arts Festival. Some of them also participated in the annual year-end festival. It was at these festivals that traditional cultural arts were showcased. All the students interviewed lamented the absence of the opportunity to "show off" their culture. Some comments were noted. Gertrude Shotte, "Education, Migration and Identities: Relocated Montserratian Secondary School Students in London Schools" (Ph.D. thesis, Institute of Education, University of London, 2002), 184, 195, 235.

23. Montserratians who migrated to the UK during the first two post-war decades are referred as "first-wave migrants."

24. Cathy Aymer, "Migration: The Irreparable Separation of Small and Large Footprints," Anthropology in Action 6, no. 2 (1999): 29-33.

25. Ibid., 29, 30.

26. The Refugee Council, Helping Refugee Children in Schools (London: The Refugee Council, 1997); Jill Rutter, Refugee Children in the Classroom (Stoke-on-Trent: Trentham Books, 1994).

27. Jane Kroger, Identity in Adolescence: The Balance between Self and Other (London: Routledge, 1989), 42.

28. This means leaving home for school but not turning up at school.

29. Coelho; Isabel Kaprielian-Churchill and Stacy Churchill, The Pulse of the World: Refugees in Our Schools (Toronto: Ontario Institute for Studies in Education Press, 1994).

30. William Cross, Jr., L. Strauss, and Peony Fhagen-Smith, "African American Identity Development across the Life Span: Educational Implications," in Racial and Ethnic Identity in School Practices: Aspects of Human Development, ed. R. Sheets and E. Hollins (London: Lawrence Erlbaum Associates, 1999).

31. The Refugee Council, 1997; Eva Segestrom, Focus on Refugee Children (Vaxjo: Grafiska Punkten, 1995); Rutter, 1994. 
32. One of the Standards Funds that is specifically designed to improve the attainment of minority ethnic pupils, in particular refugees. .

33. Cross, Jr. et al., 32.

34. Ibid., 32.

35. Ibid., 33.

36. Coelho, 20.

37. Steven Lyle, John Benyon, Anna McClure, and Jon Garland, Education Matters: African Caribbean People and Schools in Leicestershire (Leicester: University of Leicester, 1996); Yvonne Channer, I Am a Promise: The School Achievement of British African Caribbeans (Stoke-on-Trent: Trentham Books, 1995); Heidi Mirza, Young, Female and Black (London: Routledge, 1992); Mairtin Mac an Ghail, Young, Gifted and Black (Milton Keynes: Open University Press, 1988).

38. Etta Hollins, "Relating Ethnic and Racial Identity Development to Teaching," in Racial and Ethnic Identity in School Practices: Aspects of Human Development, ed. R. Sheets and E. Hollins (London: Lawrence Erlbaum Associates, 1999), 186.

39. Cross, Jr., et al., 31.

40. Ibid., 31.

41. Camino, 2.

42. Mick Cooper, "If You Can't Be Jekyll Be Hyde: An ExistentialPhenomenological Exploration on Lived Plurality," in The Plural Self: Multiplicity in Everyday Life, ed. J. Rowan and M. Cooper (London: Sage Publications, London, 1999), 61.

43. Minority Rights Group, 1998, Forging New Identities: Young Refugees and Minority Students Tell Their Stories (London: Minority Rights Group, 1998).

44. Haircuts patterned with names or symbols/logos and havint two or more parallel lines on any part of the head are considered "bizarre" hairstyles.

45. Leon Rappoport, Steve Baumgardner, and George Boone, "Postmodern Culture and the Plural Self," in The Plu- ral Self: Multiplicity in Everyday Life, ed. J. Rowan and M. Cooper (London: Sage Publications, 1999), 98.

46. Ibid., 99.

47. John Head, Working with Adolescents: Constructing Identity (London: Falmer Press, 1997), 23.

48. Rampton, 28.

49. Marlon Couldrey and Tom Morris, "Introduction: Culture in Exile," Forced Migration Review 6 (1999), 2.

50. Ibid., 4.

51. Rampton, 297.

52. Janice Panton and Robert Archer, Waiting on the Volcano: A Visit to Montserrat (London: Christian Aid, 1996), 7.

53. Ibid., 7.

54. Ibid., 23.

55. Ruth Arber, "Defining Positioning within Politics of Difference: Negotiating Spaces 'In Between," Race, Ethnicity and Education 3, no. 1 (2000): 45-64.

56. Ibid., 61.

57. James Ryan, Race and Ethnicity in Multi-ethnic Schools: A Critical Case Study (Clevedon: Multilingual Matters Ltd., 1999), 122.

58. Arber, 61.

Gertrude Shotte, M.A., Ph.D., has taught at primary, secondary, and tertiary levels in Montserrat and the UK and has carried out research on the educational experiences of relocated Montserratian students since 1997, almost immediately after the exodus to the UK. She currently tutors MA students in the School of Lifelong Education and International Development, Institute of Education, University of London.

(C) Gertrude Shotte, 2006. This open-access work is licensed under a Creative Commons Attribution-NonCommercial 4.0 International License, which permits use, reproduction and distribution in any medium for non-commercial purposes, provided the original author(s) are credited and the original publication in Refuge: Canada's Journal on Refugees is cited. 